\title{
Effects of Aqueous Leaf Extract of Paulinia Pinnata on Swimming Endurance Time of Mice
}

\author{
"Dayom DW ${ }^{1}$, Gyang $\mathrm{SS}^{2}$, Jimam $\mathrm{SN}^{1}$ and Okwuasaba $\mathrm{FK}^{2}$ \\ ${ }^{I}$ Department of Clinical Pharmacy, Faculty of Pharmaceutical Sciences, University of Jos, Nigeria \\ ${ }^{2}$ Department of Pharmacology, Faculty of Pharmaceutical Sciences, University of Jos, Nigeria
}

\begin{abstract}
The swimming test was used to investigate the effect of aqueous leaf extract of Pauliniapinnata on the swimming endurance in mice. Mice were categorized into controls and test groups and placed in plastic jar containing water maintained at $25 \pm l^{\circ} C$. Each animal was allowed to swim until exhausted and the swimming time recorded. The results revealed that the extract $(500 \mathrm{mg} / \mathrm{kg})$ and imipramine $(50 \mathrm{mg} / \mathrm{kg})$ caused significant reduction $(P<0.05)$ in swimming time compared to the control that was given normal saline. This effect is considered to be attributed to its CNS depression which diminishes ability for physical activity. Depressant activity of the extract was dose-dependent as swimming time decreased with increasing dose as revealed in the regression data. The results obtained with this extract therefore demonstrated that Pauliniapinnata leaf possess obvious depressant activity on the CNS of mice.
\end{abstract}

Key words: CNS depressant activity, Mice, Pauliniapinnata, Swimming time.

\section{Introduction}

In the search for new therapeutic products for the treatment of neurological disorders, medicinal plant research worldwide has progressed, constantly demonstrating the pharmacological effectiveness of different plant species in a variety of animal models [1].

Crude extracts of medicinal plants are usually a complex mixture of different constituents and P. pinnata is not an exception. The presence of cardiac glycosides, saponins, alkaloids and tannins have been demonstrated in Pauliniapinnata leaf [2]. These constituents are usually responsible for the different pharmacological actions of the extract. Saponins have been shown to have antidepressant activity as well as anti-inflammatory, antinociceptive and antipyretic activities [3] while alkaloids tend to have vasodilator and antipsychotic effects. Tannins also have diuretic, vasoconstrictive and antibacterial properties.

The swimming test in laboratory animals(e.g. mice)has been used widely to evaluate some pharmacological activities of various agents on the central nervous system(CNS) including CNS depressants, antidepressants, sedative hypnotics, psycho-stimulants, euphoric, nootropic, adaptogensetc [4]. The swimming test has also been used to assess antistress activity in mice and rats of phytomedicines including Panax ginseng, Withaniasomnifera, Ocimum sanctum, Sedum rosea, Aralia elata and Tiliaagentea[5]. Paulliniapinnata is a herbaceous climbing plant common in west Africa. The leaves, roots and seed are powdered together with ginger or ginger grains and applied to fractures to aid bone healing and healing of open wounds [6] and as nerve poison to cause paralysis [7]. Methanol leaveand root extracts of Pauliniapinnataare rich sources of phenolic compounds [8] while the methanol stem bark extract have been found to contain bioactive constituents which possess anti-convulsant activity [9] with a median lethal dose of $2346.42 \mathrm{mg} / \mathrm{kg}$.

The leaf was extensively used with acclaimed success in the treatment of cutaneous Leishmaniasis in Idah and Keana in Kogi and Nassarawa states of Nigeria respectively. These assertions arose during an outbreak of cutaneous leishmaniasis in these communities (oral communication), in which epidemiological studies confirm the disease [10]. Interest is therefore generated in studying its pharmacological profiles to determine its safety, considering its extensive use by leishmanial patients in the affected communities as well as its other traditional usage. In this study, the neurological effect of the aqueous leaf extract of Pauliniapinnatawas tested in mice.

\subsection{Animals}

\section{Materials and methods}

Young male albino mice 19-21days old weighing 15-19g were obtained from the animal unit, Department of Pharmacology, University of Jos and maintained on standard diet and water at libitum. Animals were handled in accordance with ethical standards. 


\subsection{Plant Material}

The plant was first obtained in Keana, Nassarawa state of Nigeria and later from herbs sellers in terminus, Jos Plateau state. The leaves were harvested from the stuck, washed with water and dried under shade. The dried leaves were pulverised into powder using wooden mortar and pestle.

\subsection{Extraction}

Fifty gram of the powdered materials was subjected to exhaustive soxhlet extraction in $200 \mathrm{ml}$ of water at $70^{\circ} \mathrm{C}$ for $72 \mathrm{hrs}$, the resultant solution was evaporated to dryness in a water bath maintained at $50-60^{\circ} \mathrm{C}$. The extract obtained was stored in a refrigerator until required for use.

\subsection{Swimming endurance in mice}

Five groups of 5 mice each aged 10-21days old and weighing between 15-19g were used. Mice in group 1 were given $0.2 \mathrm{ml}$ of normal saline intra-peritoneally (IP) as control. Mice in group 2 received $50 \mathrm{mg} / \mathrm{kg}$ body weight of the antidepressant imipramine (Tofranil APO-India) dissolved in normal saline. Mice in groups 3-5 received 250, 500 and $1000 \mathrm{mg} / \mathrm{kg}$ doses of the extract respectively prepared in normal saline. All administrations were done IP and injection volume did not exceed $0.35 \mathrm{ml}$. After administration, the animals were allowed $1 \mathrm{hr}$ before start of the experiment during which they were observed for general behaviour and Hippocratic screening. The experiment essentially involved allowing the animals to swim separately (until exhausted) in plastic jar $(38 \mathrm{~cm} \times 27 \mathrm{~cm} \times 15 \mathrm{~cm})$ containing water maintained at $25 \pm 1^{\circ} \mathrm{C}$. The endurance of each mouse was recorded as the time from the beginning of swimming to exhaustion, which was determined by observing loss of coordinated movements and eventual drowning. The mean swimming time for each group was calculated.

\subsection{Statistical analysis}

The data obtained was evaluated using the student t-test. All data represent mean values \pm standard error of the mean (SEM). P values equals to or less than 0.05 were considered significant. The dose-dependent effect of the extract on swimming performance was tested by the application of linear regression procedure.

\section{Results}

During Hippocratic screening, all the animals that received imipramine and the extract exhibited various degrees of sedation and weakness as motor activity was depressed or due to direct effect on the musculo-skeletal system.

The aqueous extract of Paulliniapinnata demonstrated significant depression of locomotor activity in the mice. The mice forced to swim in the jar after a period adopted a characteristic immobile posture which was readily noticeable. Further loss of motor activity made the animals to drawn. These effects were dosedependent, showing decrease locomotor activity characterised by decrease swimming time with increasing dose of the extract (Fig.1).

Table 1: Regression data of the effect of Pauliniapinnata extract on swimming endurance time in mice.

\begin{tabular}{llll}
\hline Group & Drug/Dose & $\begin{array}{l}\text { Swimming time (min) } \\
\text { Mean } \pm \text { sem }\end{array}$ & Regression data \\
\hline 1 & Normal saline & $46.60 \pm 0.60$ & - \\
& $0.2 \mathrm{ml}$ & & \\
& & & \\
2 & Imipramine & $38.40 \pm 1.63$ & $\hat{\mathrm{y}}=70.33+2.33 \mathrm{X}$ \\
& $50 \mathrm{mg} / \mathrm{kg}$ & $P<0.05$ & $\mathrm{r}=0.8675, \quad P<0.05$ \\
3 & Extract & $39.60 \pm 1.96$ & $\hat{\mathrm{y}}=-109.52+3.2 \mathrm{X}$ \\
& $250 \mathrm{mg} / \mathrm{kg}$ & $P<0.05$ & $\mathrm{r}=0.2036, \quad P>0.1$ \\
& & $38.20 \pm 0.37$ & $\hat{\mathrm{y}}=0.92+0.8 \mathrm{X}$ \\
4 & Extract & $P<0.05$ & $\mathrm{r}=0.5345, \quad P>0.1$ \\
& $500 \mathrm{mg} / \mathrm{kg}$ & $34.40 \pm 1.03$ & $\hat{\mathrm{y}}=-720.52+16.2 \mathrm{X}$ \\
5 & Extract & $P<0.001$ & $\mathrm{r}=0.8741, \quad P<0.05$ \\
& $1000 \mathrm{mg} / \mathrm{kg}$ & & \\
\hline
\end{tabular}




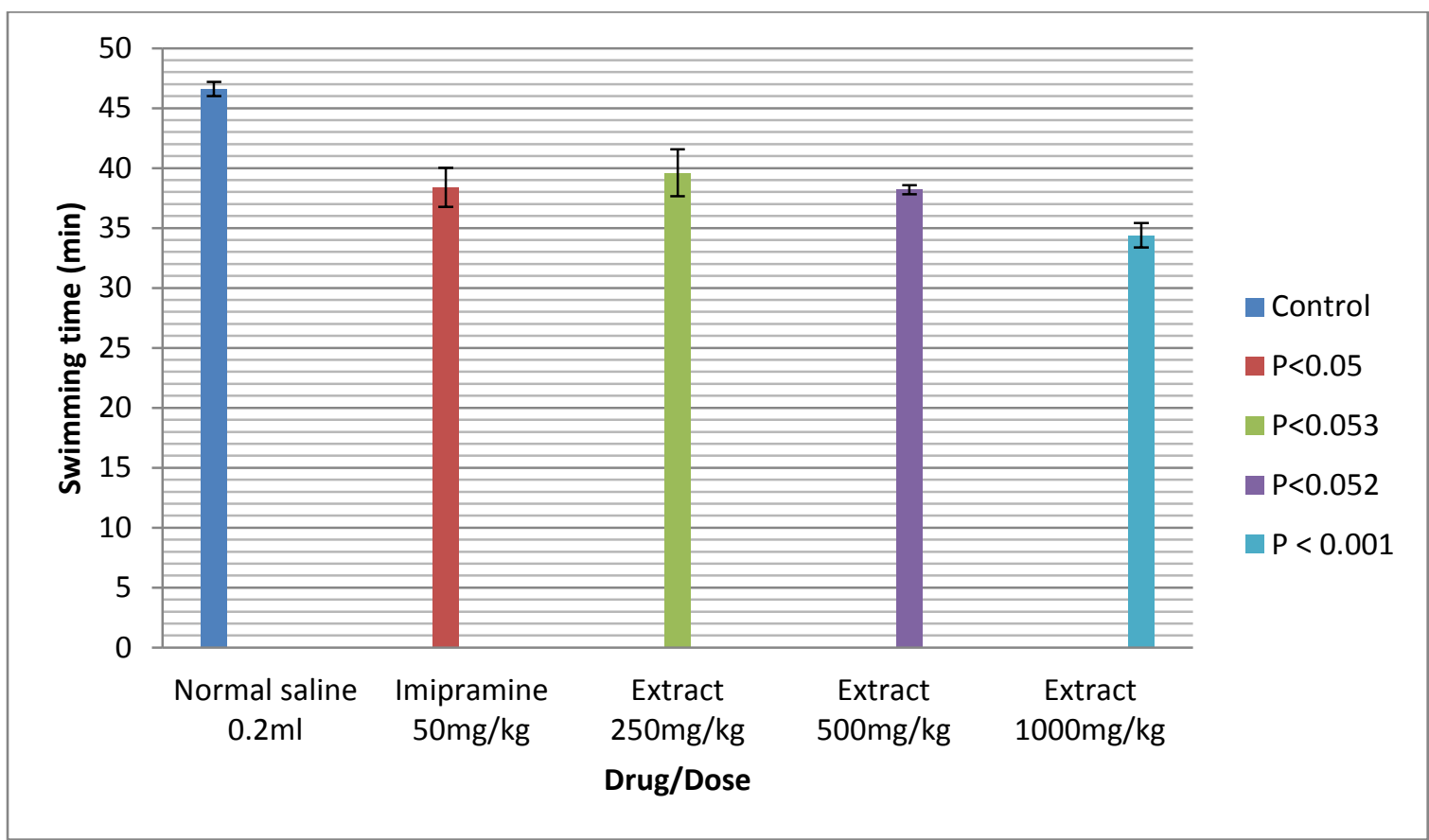

Figure 1: Effect of Paulinia pinnata aqueous leaf extract on swimming endurance time in mice

\section{Discussion}

It is often necessary to test plants extract for its activity onbiological systems to confirm its reputation in traditional usage or simply to complete its pharmacological profile. Lococmotor activity in mice involves placing a number of mice in activity cage which enable movement of the animal across a light beam to be counted as locomotion count [11].

In this experiment, water was placed in the cage and mice had to swim to remain afloat. This type of test is used to evaluate a CNS depressant or stimulant activity profile. The times taken for the mice to drown in the treated groups are lower than the control. This result shows that the aqueous leaf extract of Pauliniapinnatareduced swimming time in mice. This effect was dose-dependent, being significant $(\mathrm{p}<0.05)$ at $250 \mathrm{mg} / \mathrm{kg}$ and $500 \mathrm{mg} / \mathrm{kg}$ but highly significant $(\mathrm{p}<0.001)$ at $1000 \mathrm{mg} / \mathrm{kg}$ (Fig.1). The regression data shows that the depressant activity of $P$. pinnata extract is only significant $(\mathrm{p}<0.05)$ at the highest tested dose of $1000 \mathrm{mg} / \mathrm{kg}$ similar to the reduction obtained with the standard drug imipramine (TABLE 1). The reduced swimming time in the extract-treated mice may be attributed to CNS depression and or stress-related physical fatigue. Mice are not aquatic animals and so will easily develop fatigue trying to stay afloat when placed in water. Fatigue is defined as physical and/or mental weariness resulting in negative impacts on exercise intensity, work performance, family life, and social relationships [12]. Physical fatigue can be accompanied by deterioration in functional performance [13].

There are at least two mechanisms that can explain the occurrence of physical fatigue: oxidative stress and energy exhaustion [14]. Exhaustive or intensive exercise can lead to the accumulation of excess reactive free radicals that result in tissue damage. Exhaustion theory suggests that energy source depletion and excess metabolite accumulation can lead to fatigue [15].

The immobility seen in the mice and indeed other rodents has been demonstrated [16, 17] during swimming and this reflects behavioural despair as seen in human depression. It is possible that the decrease in swimming time observed in the treated mice is through CNS depression of motor cortex and or other higher structures in the CNS. Imipramine, a known tricyclic antidepressant prevents reuptake of nor-adrenaline and serotonin resulting in their increased availability in the synapse and therefore an increase in adrenergic and serotonergic neurotransmission [18].

This and the Hippocratic screening are generally in agreement with clinical findings that tricyclic antidepressant drugs cause sedation, dysphoria, confusion and motor incoordination in non-depressed patients during the first few days of treatment [19]. Advances made in neuroscience suggest that dysfunction of the GABAergic system in addition to monoamine deficit contributes to the pathophysiology of anxiety and depression [20].

The results obtained with this extract therefore demonstrated that Pauliniapinnata leaf possess obvious depressant activity on the CNS of mice. The observations are similar with other plants extract such as Desmodiumadsendens which cause CNS depression in rodents indicated by decreased level of spontaneous 
motor activity and lack of exploratory behaviour [21]. The bark and leaf aqueous extract of Byrsonimacrassifolia, Gliricidiasepium have been demonstrated to reduce spontaneous motor activity and exploratory conduct in mice [22].

\section{Conclusion}

Pauliniapinnata leaves has significant neurological and musculoskeletal depressant effects in rodents and so must be used systemically with caution in traditional medicine in conditions for which it is efficacious.

\section{References}

[1] Z.J. Zhang. Therapeutic effects of herbal extracts and constituents in animal models of psychiatric disorders.Life Science 75, 2004, 1659-1699.

[2] D.W.Dayom, S.S. Gyang and B.B. Bukar., Investigation of some pharmacological actions of the aqueous extract of Pauliniapinnata leaves. Journal of Pharmacy and Bioresources. 1(1), 2004, 12 - 16

[3] F.R. Melek, N.Z. Yassin, M.A. Selim and I.A.A. Kassem: Pharmacological activities of saponin-containing fraction derived from GleditsiacaspicaDesf. methanolic fruit extract. Der Pharmacia Lettre, 5 (2), 2013, 247-253.Available online at www.scholarsresearchlibrary.com accessed $7^{\text {th }}$ march 2014.

[4] O. Yusuf,A. Suleyman, O.K. Nilgun and C.B. Husnu.Effects of extracts from certain Sideritis species on swimming performance in mice.Phytotherapy res. $10,1996,70-73$

[5] D.E. Hernandez, J.L. Hancke and G. Wikman.Antiulcer and antisecretary activity of Aralia elata and Schizandrachinensis in rats.J. Ethnopharmacology. 23, 1988, $109-113$

[6] J.M. Dalziel. The useful plants of West Tropical Africa(Crown Agents for Overseas governments and administration, London. 1937), $334-335$

[7] G. Amare. Some common medicinal plants used in Ethopian fork medicine. Faculty of sciences, Addis Ababa University, Ethopia. 1976

[8] A. Zamble, M. Carpentier, A. Kandoussi et al. Paulliniapinnata extracts rich in polyphenols promote vascular relaxation via endothelium-dependent mechanism. J CardiovascPharmacol 47(4),2006, 599-608.

[9] B.B. Maiha, M.G. Magaji, A.H. Yaro, A.H. Hamza, S.T Ahmed and R.A Magaji.Anticonvulsant studies on cochlospermumtinctoriumand paulliniapinnataextracts in laboratory animals. Nigerian Journal of Pharmaceutical Sciences Vol. 8 , No. 1, 2009, $102-108$

[10] S.M. Agwale,B. Dondji, C.J. Okolo and D.D Duhlinska.Clinical and parasitological prevalence of leishmaniasis in school children in Keana, Awe LGC of Plateau state, Nigeria.Mem.Inst. Oswaldo Cruz, Rio de Janeiro. 88(2), 1993, 347

[11] T.H. Svensson and G. Thieme.An investigation of a new instrument to measure motor activity of small animals.Psychopharmacology (Berl.) 14, 1969, 157 - 163

[12] R.K. Mehta and M.J. Agnew. Influence of mental workload on muscle endurance, fatigue, and recovery during intermittent static work. Eur. J. Appl. Physiol. 112, 2012, 2891-2902.

[13] R.H. Fitts. Cellular mechanisms of muscle fatigue. Physiol. Rev. 74, 1994, 49-94.

[14] J.S. Coombes, B. Rowell, S.L. Dodd, H.A. Demirel, H. Naito, R.A. Shanely, S.K. Powers. Effects of vitamin E deficiency on fatigue and muscle contractile properties.Eur. J. Appl. Physiol.87, 2002, 272-277.

[15] L. You, M. Zhao, J.M. Regenstein, J. Ren.In vitro antioxidant activity and in vivo anti-fatigue effect of loach (Misgurnusanguillicaudatus) peptides prepared by papain digestion.Food Chem.124, 2011, 188-194.

[16] R. Porsolt, A. Bertin and M. Jalfre.Behavioural despair in mice, a primary screening test for antidepressants. Arch. Int. Pharmacodyn. Ther. 229, 1977, $327-335$

[17] R. Porsolt, G. Auton and M. Jalfre.Behavioural despair in mice, a new model sensitive to antidepressant treatments.Eur. J. Pharmacology. 47, 1978, 379 - 391

[18] M. Tatsumi, K. Groshan, R.D. Blakely, E. Richelson. Pharmacological profile of antidepressants and related compounds at human monoamine transporters.Eur J Pharmacol 340, 1997, 249-258.

[19] H.P. Rang and M.M. Dale. Pharmacology(Churchhill Livingstone, London. 1987) 513 - 529

[20] P. Brambilla, J. Perez, F. Barale, G. Schettini, J.C. Soares. GABAergic dysfunction in mood disorders.MolPsychiatry 8: 2003, 721737.

[21] P. N'gouemo, Baldy-Moulinier and C. Nguemby-Bina.Effects of an ethanolic extract of Desmodiumadscendens on CNS in rodents.J. Ethnopharmacology. 52, 1996,77-83

[22] C. Morales, M.P. Cifuentes,I. Gomez-Serranillos, A.M. Iglesias, Villardel Fresno.Neuropharmacological profile of ethnopharmedicinal plants of Guatemalia. J. Ethnopharmacology. 76, 2001, 223 - 228 